\title{
Distribution of Plecoptera in the Duero Basin (Spain)
}

\author{
M. Gonzàlez del Tánago'
}

The distribution of 37 species of Plecoptera in the Spanish area of the Duero basin is studied. A factorial analysis of the data indicates that current and substrate are the major factors controlling the distribution of the stonefly nymphs in the area. Water temperature and periodical drought have also a marked influence on such distributions.

\section{Distribution des Plécoptères dans le bassin du Duero (Espagne).}

L'auteur étudie la distribution de 37 espèces de Plécoptères dans la partie espagnole du bassin du Duero. Une analyse factorielle montre que le courant et le substrat sont les principaux facteurs qui contrôlent la distribution des laryes de Plécoptères dans cette région. La température de l'eau et l'assèchement périodique ont aussi une nette influence sur cet te distribution.

\section{1. - Introduction}

The Duero basin is one of the largest in Spain occupying nearly a fifth of the Spanish peninsular surface.

During 1981 and 1982 a general study of the area was carried out (Gonzàlez del Tánago \& Garcia de Jalón 1982) in order to establish a biotypological classification of the rivers following Persoone's (1978) proposal for a classification of water courses in the European Communities.

In this paper the results on the plecopteran fauna are discussed, particularly the species distribution in the different zones.

\section{2. - Study area and methods}

Seventy six localities distributed on 22 rivers of the Duero basin in Spain were studied. Only 58 supported Plecoptera. Their main physical characteristics have been summarized in Table I and their locations are shown on Fig. 1.

1. Dpto Hidrología, E.T.S. de Ingenieros de Montes, Ciudad Universitaria, Madrid - 3, Espana.
At each locality several physico-chemical parameters of the water were analysed and biological col. lections were carried out four times in 1981 corresponding to the four seasons. Macroinvertebrates were collected by using hand nets and by removing the substratum, separately on lotic and lentic zones.

\section{3. - Results}

Plecoptera from 7 families, represented by 17 genera and 37 species, were collected in the studied area. This represents more than a third of the species cited in the Iberian peninsula (Illies 1978).

It is worthy to mention here the presence in the area of Brachyptera vera Berthélemy \& Gonzàlez del Tánago and Taeniopteryx schoenemundi Mertens (Berthélemy \& Gonzàlez del Tánago 1983), Leuctra occitana Despax (River Duratón in Laguna de Contreras, 8.III.81: 1 Q) and Capnioneura libera Navás (River Adaja in Munotello, 15.III.81 : 1 of). These species were not cited in Spain before, alt hough some of them were recently found in Portugal (Berthélemy \& da Terra 1980).

The northern slope of the basin shelters mainly species which have a large distribution in Europe (Illies 1978) such as Brachyptera braueri Klapálek, 


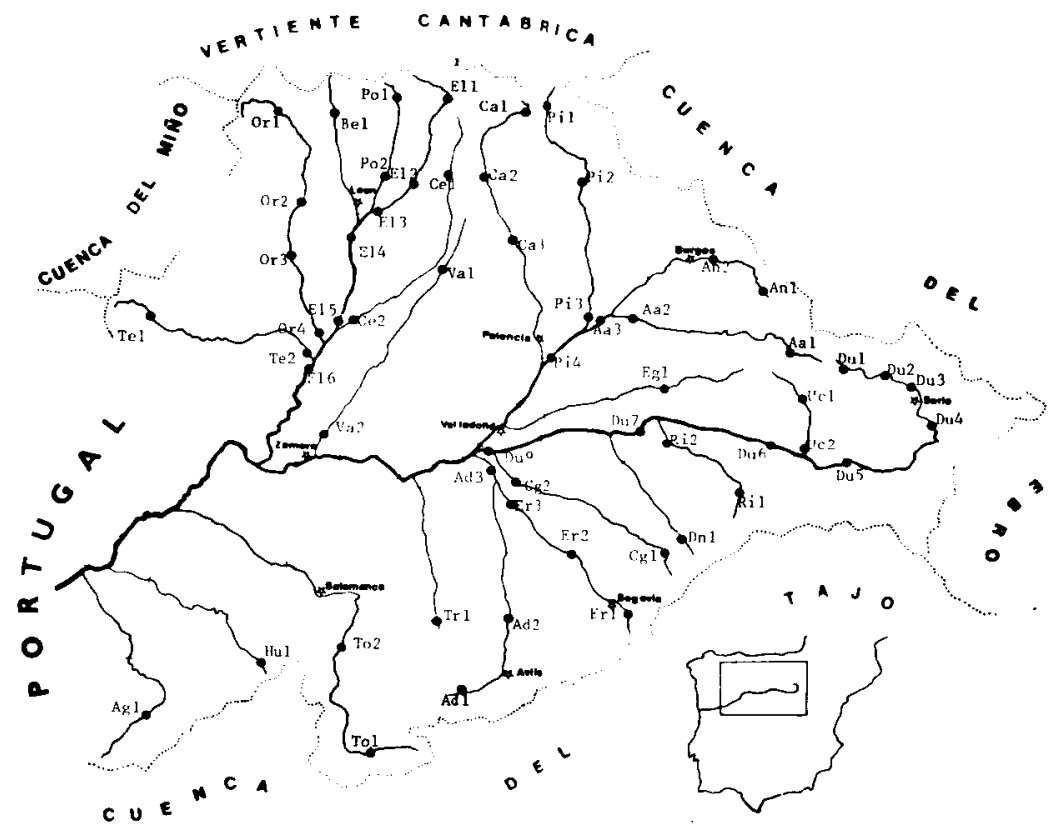

Fig. 1. Study sites in the Duero basin containing Plecoptera.

Taeniopteryx schoenemundi Mertens, Amphinemura sulcicollis Stephens, Protonemura intricata Ris, Protonemura meyeri Pictet, Euleuctra geniculata Stephens, Leuctra fusca Linne, Capnia nigra Pictet, Perlodes microcephalus Pictet, Dinocras cephalotes Curtis, Perla bipunctata Pictet and Perla marginata Pan. zer. These are sometimes also present on the southern slope of the basin, but in smaller numbers.

The most interesting region of the basin from the point of view of Plecoptera is the area of the Sistema Central which includes the Sierra of Guadarrama and Gredos. Some streams have their springs there and they shelter a large diversity of species (see Aubert 1963 ; Berthélemy \& Gonzàlez del Tánago 1983 ; Garcia de Jalón \& Gonzàlez del Tánago 1982).
A factorial analysis of the data was conducted in order to learn the relationships between species and localities. In this analysis only the semi-quantitative aquatic samples were considered. The results for the four sampling periods were summarized and the relative abundance of each species was determined by establishing 8 classes along a geometric series of rate 2 , in order to eliminate the influence of large numbers (Table II).

Factorial analysis was first used on river ecosys. tems by Verneaux (1973) and subsequently by others (Giudicelli 1980; Gonzàlez del Tanágo \& al. 1981). It allows an elucidation of the biological structure of the river communities. 
Table I. Principal physical characteristics of the sampling stations.

\begin{tabular}{|c|c|c|c|c|c|c|c|c|c|c|}
\hline & River & Station & $\begin{array}{l}\mathrm{Kn} \text { to } \\
\text { source }\end{array}$ & Alt & $\begin{array}{l}\text { titude } \\
m\end{array}$ & Slope & $\begin{array}{l}\text { Width } \\
\mathrm{m}\end{array}$ & Substratum & $\begin{array}{l}\text { Mean Summe } \\
\text { Temperatur }\end{array}$ & Observations \\
\hline \multirow{8}{*}{\multicolumn{2}{|c|}{ R. Duero }} & Dul & 8 & 1 & 200 & 25 & 7 & Stones & 17.0 & \\
\hline & & Du2 & 45 & 1 & 880 & 3.2 & 25 & Gravel & 16.5 & Below a dam \\
\hline & & Du 3 & 78 & 1 & 010 & 2.1 & 25 & Gravel & 18.5 & \\
\hline & & Du4 & 115 & & 980 & 0.8 & 17 & Sand & 19.5 & \\
\hline & & Dus 5 & 200 & & 900 & 0.9 & 31 & Grave1 & 19.5 & \\
\hline & & Du6 & 285 & & 860 & 0.5 & 30 & Gravel & 19.5 & \\
\hline & & Du 7 & 384 & & 750 & 0.9 & 53 & Grave 1 & 22.0 & \\
\hline & & Dư & 503 & & 690 & 0.6 & 36 & Grave1 & 22.5 & \\
\hline \multirow[t]{2}{*}{ R. } & Ucero & Uc 1 & 34 & & 980 & 10 & 11 & Stones & 12.0 & \\
\hline & & Uc 2 & 78 & & 890 & 2 & 10 & Stones & 19.5 & \\
\hline \multirow[t]{4}{*}{ R. } & Pisuerga & Pil & 10 & 1 & 080 & 15 & 15 & Stones & 17.0 & \\
\hline & & $\mathrm{Pi2}$ & 113 & & 870 & 1,1 & 30 & Gravel & 16.0 & Below a dan \\
\hline & & Pi3 & 216 & & 770 & 1 & 30 & Grave1 & 21.5 & \\
\hline & & $\mathrm{Pi} 4$ & 244 & & 740 & 1.1 & 46 & Gravel & 22.0 & \\
\hline \multirow[t]{3}{*}{ R. } & Arlanza & Aa $\mathbf{I}$ & 8 & 1 & 090 & 5 & 9 & Stones & 22.0 & \\
\hline & & $\mathrm{Aa} 2$ & 160 & & 790 & 2 & 30 & Stones & 21.0 & \\
\hline & & Aa 3 & 180 & & 770 & 1 & 43 & Gravel & 21.5 & Relatively polluted \\
\hline \multirow[t]{2}{*}{ R. } & Arlanzón & Anl & 10 & 1 & 200 & 14 & 6 & Stones & 15.5 & \\
\hline & & An 2 & 48 & & 920 & 7.4 & 12 & Stones & 18.0 & \\
\hline R. & Esgueva & $\mathrm{Eg} 1$ & $7 i 1$ & & 880 & 6 & 7 & Stones & 19.0 & \\
\hline \multirow[t]{3}{*}{ R. } & Carrión & $\mathrm{Cal}$ & 23 & 1 & 300 & 13 & 12 & Stones & 18.5 & \\
\hline & & $\mathrm{Ca} 2$ & 104 & 1 & 000 & 3.7 & 20 & Stones & 18.0 & Relow a dam \\
\hline & & $\mathrm{Ca} 3$ & 170 & & 790 & 3. 2 & 18 & Stones & 20.0 & \\
\hline \multirow[t]{2}{*}{$\mathrm{R}$. } & valderaduey & Val & 54 & & 810 & 5 & 7 & Stones & 26.0 & Summer drought \\
\hline & & $\mathrm{Va} 2$ & 188 & & 650 & 1.6 & 7 & Crave1 & 25.0 & Channalized \\
\hline \multirow[t]{6}{*}{ R. } & Esla & EII & 23 & 1 & 090 & 13 & 11 & Stones & 19.0 & \\
\hline & & E12 & 76 & & 870 & $4 \cdot 2$ & 32 & Stones & 19.0 & \\
\hline & & E13 & 102 & & 790 & 3.1 & 62 & Grave1 & 20.0 & \\
\hline & & E14 & 112 & & 780 & 1 & 50 & Gravel & 21.5 & \\
\hline & & E15 & 153 & & 730 & 1.2 & 45 & Gravel & 21.5 & \\
\hline & & E16 & 190 & & 690 & 1.1 & 100 & Gravel & 23.0 & \\
\hline \multirow[t]{2}{*}{ R. } & Cea & Cel & 42 & & 900 & 3 & 10 & Stones & 18.0 & \\
\hline & & $\mathrm{Ce} 2$ & 150 & & 720 & 1.7 & 8 & Grave 1 & 22.0 & \\
\hline \multirow[t]{2}{*}{$R$. } & Porma & Pol & 9 & 1 & 180 & 9 & 14 & Stones & 14.0 & \\
\hline & & Po2 & 50 & & 870 & 7.6 & 32 & Stones & 13.0 & Below a dam \\
\hline $\mathbf{R}$. & Bernesga & Be 1 & 10 & 1 & 100 & 12 & 7 & Stones & 16.0 & \\
\hline \multirow[t]{4}{*}{$\mathrm{R}$. } & Orbigo & Or 1 & 12 & 1 & 200 & 13 & 25 & Stones & 14.0 & \\
\hline & & Or2 & 70 & & 880 & 5.5 & 41 & Stones & 16.0 & Below a dalt \\
\hline & & $0{ }^{3}$ & 112 & & 780 & 2,4 & 30 & Gravel & 22.0 & \\
\hline & & $0{ }^{4}$ & 170 & & 740 & 0.7 & 35 & Grave1 & 22.0 & \\
\hline \multirow[t]{2}{*}{ R. } & Tera & Tel & 30 & & 900 & 11 & 14 & Stanes & 18.0 & Below a 1 ake \\
\hline & & $\mathrm{Te} 2$ & 130 & & 690 & 2.1 & 45 & Grave 1 & 24.0 & Below dans \\
\hline \multirow[t]{2}{*}{$\mathrm{R}$. } & Riaza & Ril & 5 & 1 & 150 & 20 & 3 & Stones & 14.0 & \\
\hline & & $\mathrm{Ri2}$ & 116 & & 770 & 3.4 & 7 & Gravel & 18.0 & Below dams \\
\hline $\mathrm{R}$. & Duratón & Dn 1 & 13 & 1 & 000 & 8 & 6 & Stones & 23.0 & Summer drought \\
\hline \multirow[t]{2}{*}{$\mathrm{R}$. } & Cega & $\mathrm{Cg} \mathbf{1}$ & 22 & & 900 & 6 & 9 & Grave 1 & 23.0 & Summer drought \\
\hline & & $\mathrm{Cg} 2$ & 142 & & 690 & 1.8 & 11 & Sand & 25.0 & Summer drought \\
\hline $\mathrm{R}$. & Eresma & Erl & 8 & 1 & 250 & 20 & 7 & Stones & 16.0 & \\
\hline & & Er2 & 60 & & 800 & 8.7 & 10 & Stones & 22.0 & \\
\hline & & Er3 & 103 & & 720 & 1.9 & 11 & Sand & 24.0 & Summer drought \\
\hline & Adaja & Adl & 10 & 1 & 100 & 6 & 7 & Gravel & 19.0 & Summer drought \\
\hline & & Ad 2 & 72 & & 860 & 2.4 & 10 & Grave: & 20.0 & \\
\hline & & Ad 3 & 170 & & 690 & 1.7 & 23 & Sand & 27.0 & Summer drought \\
\hline R. & Trabancos & $\operatorname{Tr} 1$ & 17 & & 920 & 9 & 2 & Sand & 23.0 & Summer drought \\
\hline & Tormes & Tol & 22 & 1 & 180 & 10 & 16 & Stones & 20.0 & \\
\hline & & To? & 102 & & 850 & $4 \cdot 1$ & 27 & Grave 1 & 21.5 & Below a dam \\
\hline $\mathrm{R}$. & Huebra & Hu 1 & 14 & & 840 & 8 & 3 & Stones & 25.0 & Periodical drought \\
\hline $\mathrm{R}$. & Agueda & $\mathrm{Agl}$ & 13 & & 810 & 12 & 15 & Stones & 24.0 & \\
\hline
\end{tabular}


Fig. 2 represents the results of such an analysis. Although no clear structure can be detected, since many species of Plecoptera are present in most of the localities considered, some remarks on the relationships among species can be made by taking into account their relative positions among the localities.

Seven groups of species and localities can be differenciated in the figure and fitted into the zonation system of Illies \& Botosaneanu (1963) as follows (Fig. 2) :

- $\mathrm{G}_{0}$ : includes localities which correspond to the Crenon and Epirhithron, with swift current and soft waters. This zone is characterized by Siphonoperla torrentium, the spring-emerging Leuctra ( $L$. hippopus) and Amphinemura sulcicollis which are all relatively frequent in the upper reaches of the rivers Riaza and Eresma, in the Guadarrama mountains.

$-\mathrm{G}_{1}$ : includes the upper reaches of the main rivers studied, all of them oligotrophic and considered as Epirhithron. The Perlidae Dinocras cephalotes, Perla marginata and Perla grandis characterize this zone.

Although they are in the same group, Dinocras cephalotes is placed at a higher typological level than Perla marginata which is also abundant in other localities where a more tolerant species community exists. Dinocras cephalotes has been found only in the most oligotrophic sites. living in both lotic and lentic sections of the rivers. Perla marginata has been collected only in the sites exposed to the current. Some collections confirm the ecological distribution patterns of these two species described by Hynes (1941) and Berthélemy (1966), but others show the opposite. In the upper reaches of the river Ucero (Ucl) where there are huge populations of macrophytes, only Perla marginata has been recorded; the upper reaches of the rivers Pisuerga (Pil). Esla (EII), Porma (Pol) and Bernesga (Bel) have a substrate which is relatively unstable and is barely covered by moss ; Dinocras cephalotes is much more abundant there than Perla marginata.

- $\mathrm{G}_{1}^{\prime}$ : corresponds to the upper reaches of some rivers which harbour a macroinvertebrate fauna similar to those of localities situated at lower reaches in other rivers, no doubt because of the organic enrichment of the water or its higher temperatures. Capnioneura ssp. and Protonemura meyeri reach their largest densities in some of the stations in this group.
$-\mathrm{G}_{2}$ : is represented by localities corresponding to the Metarhithron; these always have a stony substrate on which some Perlidae and Perlodidae species live. Autumnemerging Leuctra ( $L$. gr. fusca) are also very common in this area.

$-G_{3}$ : this group contains localities belonging to the Hyporhithron. The species of Plecoptera relatively tolerant to organic enrichment inhabit this zone. Species of Taeniopterygidae and Capniidae are very common during the winter months.

$-\mathrm{G}_{3}^{\prime}$ : corresponds to the rivers situated in the south east of the basin which dry up in summer. Although some of these localities belong to the upper reaches of the rivers, they become very warm and have high conductivity in summer. Their fauna is therefore similar to that of other localities situated far downstream in other rivers.

Species of Taeniopterygidae and Capniidae are also very common in this area that can only support a Plecoptera fauna during winter. The biological cycle of these species, which are adult in early spring, is a very good strategy for colonizing such places where temperature and dissolved oxygen content limit the presence of other Plecoptera with later emerging periods.

$-G_{4}$ : represents the lowest region of the rivers studied in which Plecoptera exist. It corresponds to the Epipotamon; it is clearly defined in winter when the Taeniopterygidae, the only Plecoptera in this zone, are abundant. Brachyptera brateri is the commonest and most characteristic species of the basin and is sometimes the only species of Plecoptera to occur.

\section{4. - Discussion}

In Fig. 2, the localities are spread along the first factorial axis following their altitudinal gradient, except in the cases mentioned above. Dinocras cephalotes and Brachyptera brateri are the species which contribute most to the first axis $15 \%$ and $40 \%$ respectively). Therefore the axis represents the "zonation" or the natural succession of localities from upstream downwards the rivers studied.

The influence of a variety of factors related to river zonation on the abundance and distribution of lotic insects has been pointed out many times (Hynes 1970, Hawkes 1975). The movement of the water, altitude and substrate control the distribution of sto- 
Table II. Relative abundance of Plecoptera species considered in the factorial analysis in the Duero basin (aquatic samples and species which were present in at least five localities).

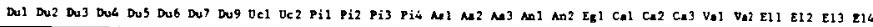

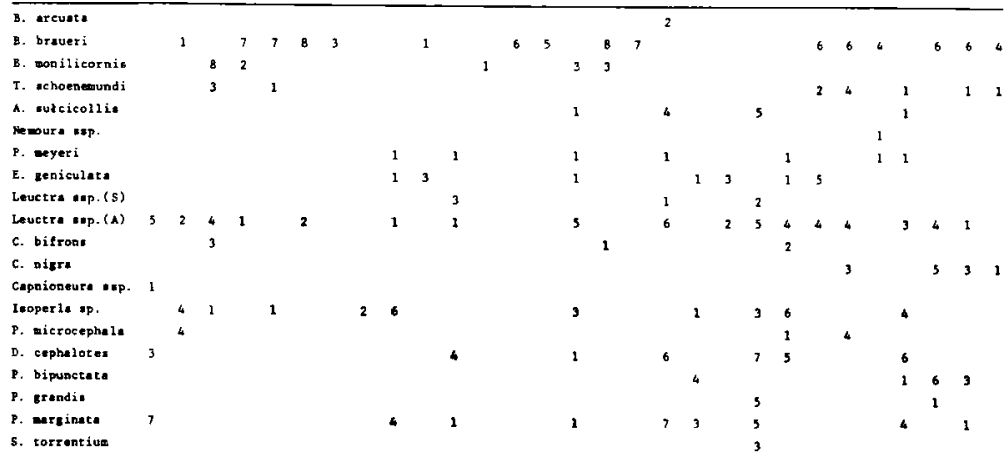

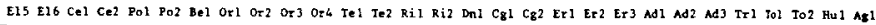

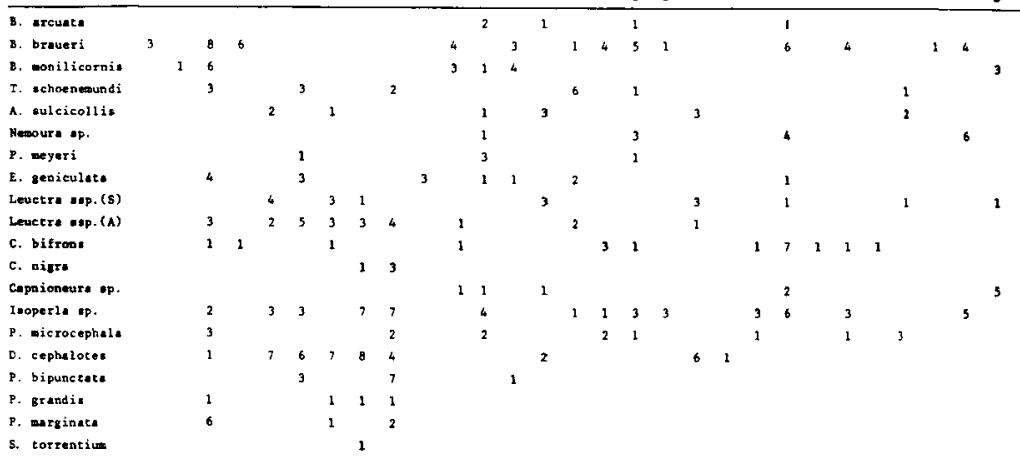

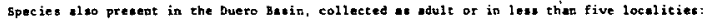

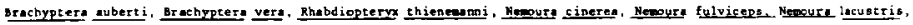

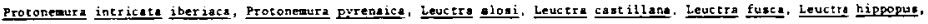
Leuctra hispanice. Leuctra gedricensil, Leuctra meroscans, Leuctra occicata, Capnioneure liberd, Capnioneura eicin, Hemimelena flaviventric, Ferla burme isterima, chloroperla tripunctate. 


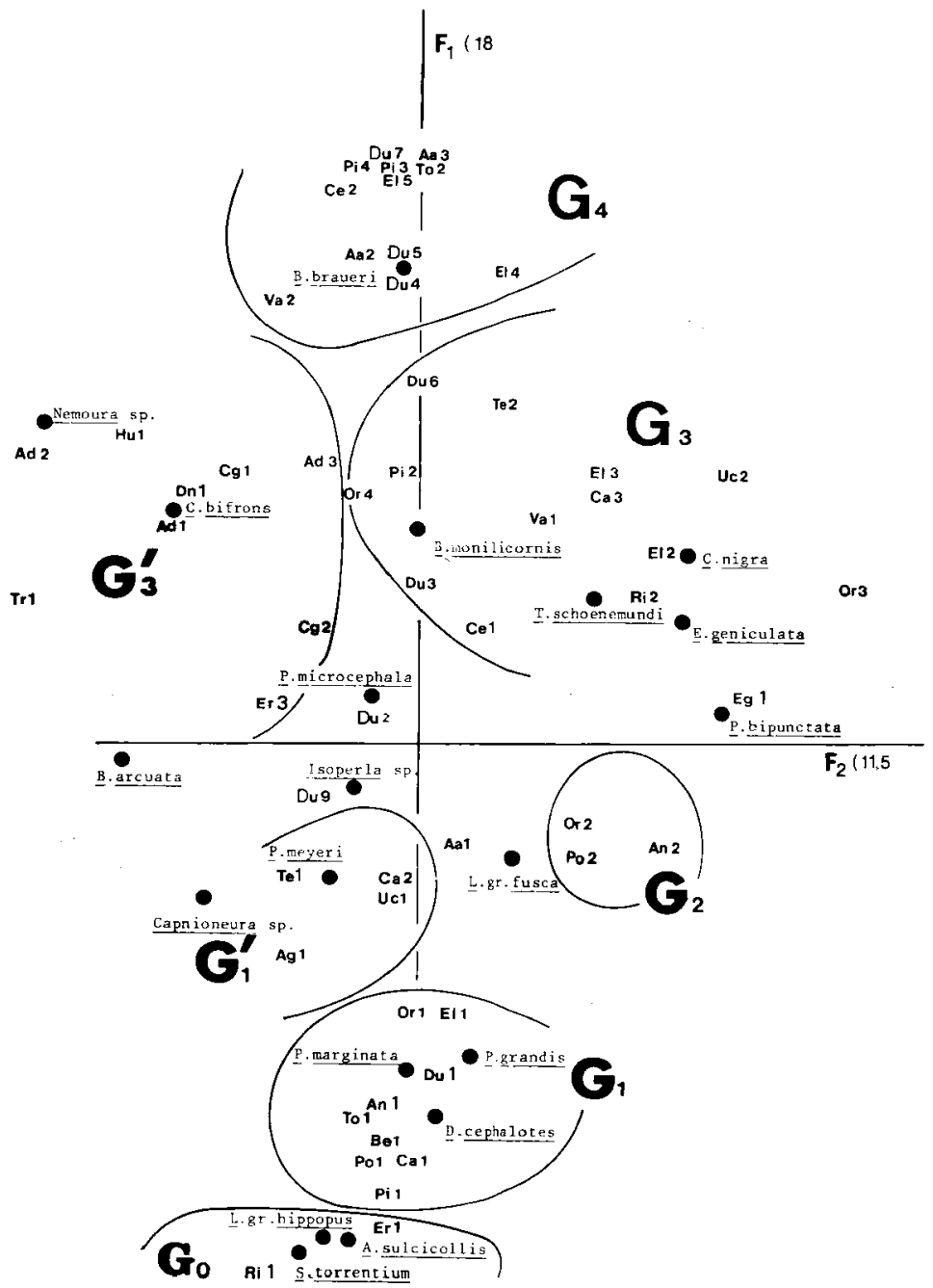

Fig. 2. Factorial analysis of Plecoptera fauna in the Duero basin (Spain). 
nefly nymphs in some areas (Hynes 1941, Brinck 1949, Berthélemy 1966) and temperature and food are considered as primary factors in others (Kamler 1965, Lillehammer 1974, Ward 1982).

In Fig. 2, the localities with turbulent current and stony substrates are located towards the negative values of the first factorial axis and the ones with uniform water flow and gravel or sandy bot tom are situated at the opposite, towards the positive end of the axis. It seems that these parameters, viz. current and substrate, are those most correlated to the first axis (which represents the "zonation ") and they can be considered as the major factors control. ling the distribution of the plecopteran fauna in the Duero basin.

The second factorial axis seems to be determined by the distribution of some species which inhabit only the northern slope of the basin, such as Capnia nigra, Euleuctra geniculata and Perla bipunctata, and of others which are more abundant in the southem areas such as Nemoura sp. and Capnia bifrons. The factors which most differenciate these two slopes are temperature (much lower in the north) and drought (relatively frequent in the south).

The influence of drought on stonefly nymphs distribution has been stated before (Hynes 1941). It seems that the factors mentioned are those that determine the structure of the Plecoptera communities although each one takes a different relative weight according to the natural characteristics of the area.

\section{Acknowledgements}

My special thanks to Dr. C. Berthélemy (Toulouse) for his helpful taxonomic assistance.
Literature cited

Aubert (J.J. 1963. - Les Piécoptères de la péninsule ibérique Eos, $39: 23-107$.

Berthelerny (C.). 1966. - Recherches écologiques et biogéographiques sur les plécoptères et coleopteres d'eau courante \{Hydraena et Elminthidae\} des Pyrénées. Annls Limnol. 2 : 227.458

Berthélemy (C) \& da Terra (L.S.W.) 1980. - Plecoptères du Portugal (Insecta) Annls Limmol. 16, 159.182.

Berthélemy (C) \& González del Tanago (M.). 1983. - Les Taeniopterygidae du bassin du Duero (Insecta: Plecoptera) Anmls Limnol., $19(1): 9-16$.

Brinck (P.). 1949 - Studies on Sitedish stoneflies (Plecoptera). Opusc. ent. Stuppl 11:250 p

Garcia de Jajón (D.) \& González del Tanago (M.) - 1982. Introducción a una zoosociologia del macrobentos de la Sierra de Guadarrama. Bol. Est. cent. Ecol., $21: 63.71$.

Giudicelli (J.). Dia (A.) \& Légier (P.). 1980. - Eutde hydrobiologique d'une rivière de région méditerranéenne, l'Argens (Var, France). Bijdragen tot de Dierkunde, 50 (2) : 303-341.

Gonzalez del Tánago (M.), Garcia de Jalón (D.) \& Gonzàlez Alonso (F.). 1981 . - Estudio de la estructura biotipológica del rio Jarama. Bol. Est. cent. Ecol., $19: 33-51$.

Gonzàlez del Tánago (M.) \& García de Jalón (D.\$. 1982. - Estudio para una mecodologia de clasif icación biotipológica de los rios espanoles. Aplicación a la Cuenca del Duero. CEOTMA. MOPU. Madrid

Hawkes (H.A.). 1975, - River zonation and classification. p. 312-374 in: Whitton B.A. (ed.), Rivers Ecology. Blackwell Sci. Publ. Oxford.

Hynes (H.B.N.). 1941. - The taxonomy and ecology of the nymphs of British Plecoptera with notes on the adulis and eggs. Trans. R. ent. Soc. Lond, 91 : $459-557$.

Ilies (J.) 1978. - Plecoptera. P. 264.273 in Iblies, J. (ced.), Limmofatma Europaea. Stuttgart.

Illies (J.) \& Botosaneanu (L.). 1963. - Problemes et méthodes de la classification et de la zonation écologique des caux courante's, considérées surtout du point de vue faunistique. Mirt. int. Verein. theor angew Limnol. 12, $57 \mathrm{p}$

Kamler (E.). 1965. - Thermal conditions in mountain waters and their influence on the distribution of Plecoptera and Ephemeroptera larvae. Ekol. Pol. Ser. A. $13: 377-414$.

Lillehammer (A.). 1974. - Norwegian stoneflies. II. Distribution and relationships to the environment. Norskentomol. Tidsskr., $21: 195-250$

Persoone (G.) 1978 - Proposal for a biotypological classification of watercourses in the European Communities. Procs. Int. Symp. Biol. Ind. Water Ouality. Newcastle-upon-Tyne, England.

Verneaux (J.). 1973. - Recherches écologiques sur le réseau hydrographique du Doubs. Essai de biotypologie. Thèse de doctorat d'Erat Umiv Besançon, 260 p.

Ward (J.V.). 1982. - Altitudinal zonation of Plecoptera in a Rocky Mountain Stream. Aquatic Insects, 4 (2): $105-110$. 